\title{
TRANS-EUROPEAN ENERGY INFRASTRUCTURE PROJECTS. THE CASE OF THE NORTH-SOUTH GAS CORRIDOR
}

\begin{abstract}
Energy security is a major element of a country's national security system. Energy security hinges in particular on energy infrastructure, i.e. transmission, distribution, and storage facilities. There are at least two factors that determine the importance of energy infrastructure as an element of the national security system. One refers to the need to provide regular and uninterrupted supplies of natural gas. The other largely determines the role of the country in a given region. Consequently, energy infrastructure is a sine qua non prerequisite to ensuring energy security. Given the changes on the international arena and an ever growing demand for natural gas in the member states of the Visegrad Group, there is a pressing need to further develop infrastructural links. The North-South Gas Corridor which spans Poland, Czech Republic, Hungary, Slovenia, Croatia, and Romania, is an investment project aimed at increasing energy security in the region by diversifying the sources of natural gas. However, in view of the ever changing political situation, crucial questions need to be raised. What will be the significance of this investment for the EU and, specifically, for the countries involved in carrying it out? What are the opportunities offered when the project is completed? Will the proposed gas corridor have an effect on the geopolitical situation of Central Europe?

This article is an attempt at answering these questions. It is divided into three parts. The first part focuses on common features of the states which participate in the project. The second part analyses the progress made so far, and the third part discusses the role of the corridor for the EU and for the member states of the Visegrad Group.
\end{abstract}

Keywords: energy security, energy infrastructure, the Visegrad Group, energy policy.

\section{INTRODUCTION}

Energy security hinges in particular on energy infrastructure, i.e. transmission, distribution, and storage facilities. There are at least two factors that determine the importance of energy infrastructure as an element of the national security system. One refers to the need to provide regular and uninterrupted supplies of natural gas ${ }^{2}$. The other largely determines the role of the country in a given region. Consequently, energy infrastructure is a sine qua non prerequisite to ensuring energy security. In the other words, the energy infrastructure is the main element to counteract challenges and threats ${ }^{3}$,

\footnotetext{
${ }^{1}$ JustynaTrubalska, PhD, Faculty of Administration and Economics,University of Economics and Innovation in Lublin, Poland, e-mail: justyna.trubalska@gmail.com

${ }^{2}$ F. Bauman, Energy Security as multidimensional concept, "CAP Policy Analysis" 2008, No 1, p.5.

${ }^{3}$ P.Turowski, Bezpieczeństwo dostaw gazu dla Grupy Wyszehradzkiej i pozostatych państw Unii Europejskiej, „Bezpieczeństwo Narodowe” 2014, No 2, Biuro Bezpieczeństwa Narodowego, Warszawa 2014, pp. 112-115.
} 
at the same time to create conditions that assure the new opportunities to strengthen of energy security, as well. This kind of understanding infrastructure dimension of energy security is legitimate reason to ensuring its physicaldimensions, that defines capability of states or regional group to ensure sufficient and affordable supply of energy at any time. There is a determinant of the geopolitical role of states, simultaneously. The realization energy investment projects are important to energy security and strengthen of its role in the region. A new dynamics as a result of the 2006, 2009 or 2011 energy crises proved the lack gas infrastructure is the serious problem of energy security, in particular, in this part European Union ${ }^{4}$. As a result the states which have not well-developed energy infrastructure are exposed to the threats and all their negative consequences. These changes can influenceto the state function for all its dimensions: political, economic, and ecologic. The level of energy security is dependent on many additional factors like numbers of gas suppliers, having gas stocks in the required amount which will not allow any interference for the economyetc.In addition, this determinants define the sensitivities and vulnerabilities of the states to this kind of threats. It would seem that each situations in energy field could bring a plenty of ambiguous situationsfor the states and the region. In this context, ensuring energy security requires a wide approach, which includes both actions accomplish by the states and multilateral cooperation, which make some efforts to change the role of states in the region, and building a network between states. This kind of actions change the role of states in the region, and to enlarge its economic and political capacity. Therefore, the states have to take up the common and coherent actions for ensuring and improving their energy security, and there is a crucial term to build energy security, at all. Besides, international relations are constantly changing and growing, and it is a strongneed to conform to exist in the circumstance.After Nord Stream has been starting up, the role of Central Europe region was changed. The investment has been changing the way to think about energy policy and energy security in this part of Europe. The main feature is lack of gas connection between states in the region, therefore, causing the most important challenge for their security. Before an examination of the energy infrastructure project's role, it should define the border of this subregion, because itsboundaries are notcompletely identified. However, we usually have in mind when we talk about Central Europe is the region which includes the countries cooperation within the Visegrad Group (V4): Poland, the Czech Republic, Hungary, Slovakia, and the wider formula (V4+) includes Bulgaria, Croatia, and Romania. The Visegrad Group held on February 1991. At the beginning, the main reason of relationships were launched frameworks for political dialogue and regional cooperation.

Nevertheless, the V4 countries pointed towards own economic and social development that the process of integration in this frame was weaken what it entails.Likewise, the V4 had not focused on some energy issues until 2009. The next energy crisis proved that diversification of gas supply has been a strategic priority for the European Union and the Visegrad Group, as well. That situation played a key role in the change of international

${ }^{4}$ M.Ruszel, Security in the natural gas supplies to the countries of the Visegrad Group, International Multidisciplinary Scientific Conferences on Social Sciences \& Arts, SGEM Conference on Political Sciences, Law, Finance, Economics \& Tourism, 3-9 September 2014, Bulgaria (ISSN: 2367-5659), Conference Proceedings, Volume 1, Albena 2014, pp. 3, https://www.academia.edu/8851870/Security_in_the_natural_gas_supplies_to_the_countries_of_the _Visegrad_Group, access on 01/05/2015. 
relation in the region and demonstrated that the V4 countries were in need to change the way of the ensuring of energy security. Due to the lack energy infrastructure and similarity in their own energy mix the V4 countries have their reinforcement capability of the EU's energy security. The achievement of this aim requires to build strong cooperation among group members and to take an action towards energy security and the way to ensure it in a similar situation in the future.

The paper focuses on gas sector. The reason this approach is that, gas customers are linked to supplier by pipes and no ability to secure an alternative supply. In this context, it is necessity to answer few questions. What will be the significance of this investment for the EU and, specifically, for the countries involved in carrying it out? What are the opportunities offered when the project is completed? Will the proposed gas corridor have an effect on the geopolitical situation of Central Europe?

This article is an attempt at answering these questions. It is divided into three parts. The first part focuses on common features of the states which participate in the project. The second part analyses the progress made so far, and the third part discusses the role of the corridor for the EU and for the member states of the Visegrad Group.

\section{THE CURRENT SITUATION IN THE VISEGRAD GROUP}

In current, the import of natural gas and the other energy sources is essential to action of states. It is caused by unequally distribution of energy sources in the world. It has influenced of the import dependenceand is a source of opportunities and challenging for states. Nevertheless, the import dependence could be strengthenedby many factors, the key one is a lack of the energy infrastructure ${ }^{5}$. We can see that dependence in Central Europe. The goal of this part is presented some similarities of the V4 countries, which help to show the main circumstances of the integration in energy field.

In the member states which have acceded to the EU in 2004, there are the common history and capability for security.Indeed, we can find many differences of the energy situation among the new members and the old members, which is the reason different perception of challenges and threats for energy policy.The energy determinants have also influence on energy y policy. When bipolar system collapsed, the states which participated to the Easternblocinherited inter alia energy infrastructures ${ }^{6}$. It is adaptation to receiving gas supplies from the east, without any alternative to receive gas from other directions, at the same time.The Russian Federationstill remains a dominant gas supplier in the region.The limited gas resources and the consumption growth of natural gas in the region strengthen an unfavorablesituation. As far the most important issue of common EU energy infrastructure is one-side dependence. It defines the purpose of energy policy both in the V4 countries and the EU. But the same time we can observe that theV4 countries have many ways and solutions for their energy policy, but they do not have the common energy policy, as well.Also, the common feature is lack of balance between production and consumption natural gas in the V4 countries (figure 1).It is worth to notice that the import of natural gas is provided to the region by one direction.It has an influence on political and economic dimension energy security. On the one hand, the states which

${ }^{5}$ J. Trubalska, Bezpieczeństwo energetyczne Rzeczypospolitej Polskie, Polskie Towarzystwo Geopolityczne, Kraków 2015, pp. 83.

${ }^{6} \mathrm{~K}$. Pronińska, The Impact of Energy Cooperation of Central Europa Countries on the Regional Energy Policy of the EU, The Natolin European Central, Warsaw 2013, pp. 116-118. 
dependent on the only source of supply are exposed to political blackmail. In the extreme case, it would bring to failure of state structures. It means, the state cannot make own decisions. On the other hand, the disturbance on economic dimension energy security can negative influence on national economy.

Figure 1. Production, consumption and import of natural gas in 2013 in the V4 countries (billion cubic metres)

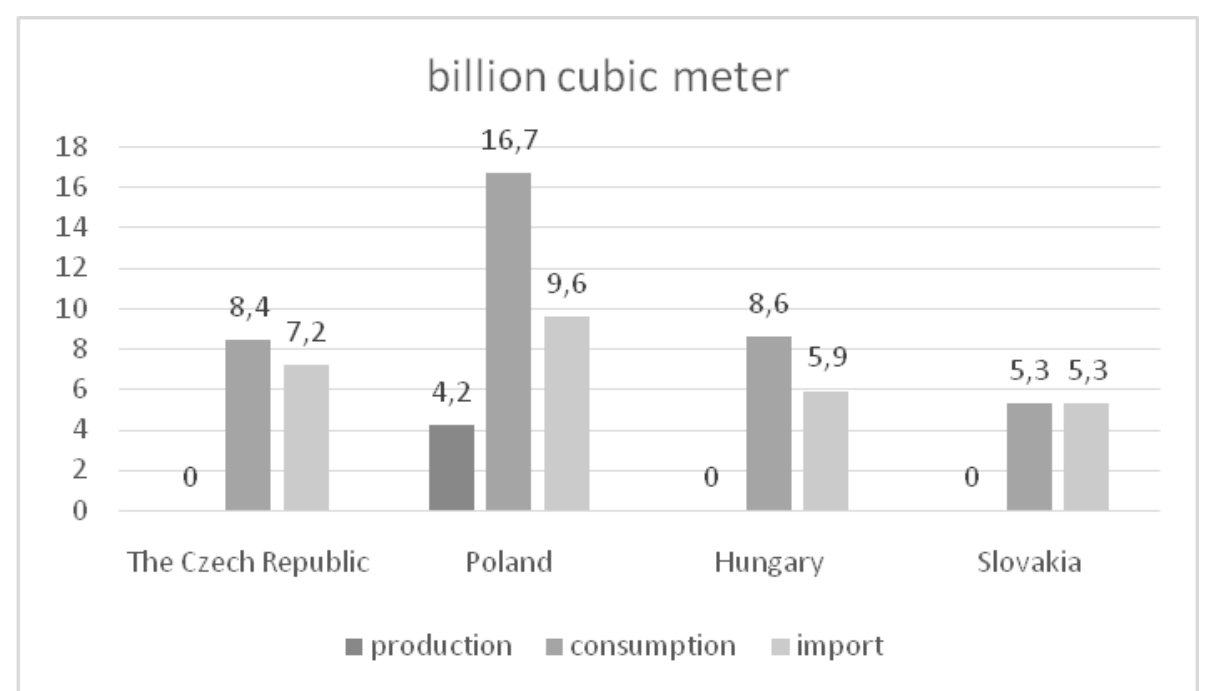

Source: BP Statistical Review of World Energy June 2014, pp. 20-29, access on: bp.com/statisticalreview

Let us examine the main features and the main determinants energy security in this region. As was emphasised above, in the region lacks of gas resources and the states are forced to take action toward diversification their energy mix, as well as, to enlarge the gas suppliers and to expand the directions of gas transit routes in the region. Secondly, the energy links are not adjustability to receiving of natural gas from other direction, besides east direction in amount which ensuring development of states. AsKamilaPronińska noted "The main issue of Central European countries is the lack of adequate number and quality of infrastructure connections with countries in the region and other EU member states, including in particular reverse-flow pipelines, alternative pipelines and import pipelines, LNG terminals and a greater transmission capacity of existing transport routes for gas, oil and petroleum products" $"$. Thirdly, it has influenced by energy dependence, which informs how strongly a national economy is dependent on one supplier. The high index of energy dependence in the region is an aftermath of lack of good solutions in the scope of energy infrastructures, in particularly. While, the energy dependence index in the V4 countries is similar, and the average above 70 per cent (figure 2).During, the average energy independence in the EU states is about $65,5 \%{ }^{8}$.

\footnotetext{
${ }^{7}$ Ibid., op.cit, pp. 139.

${ }^{8}$ Energy, transport, and environment indicators 2014 edition, Eurostat, Luxemburg 2013, pp. 75.
} 
Figure 2. Energy dependence - natural gas in the V4 states $2012(\%)$

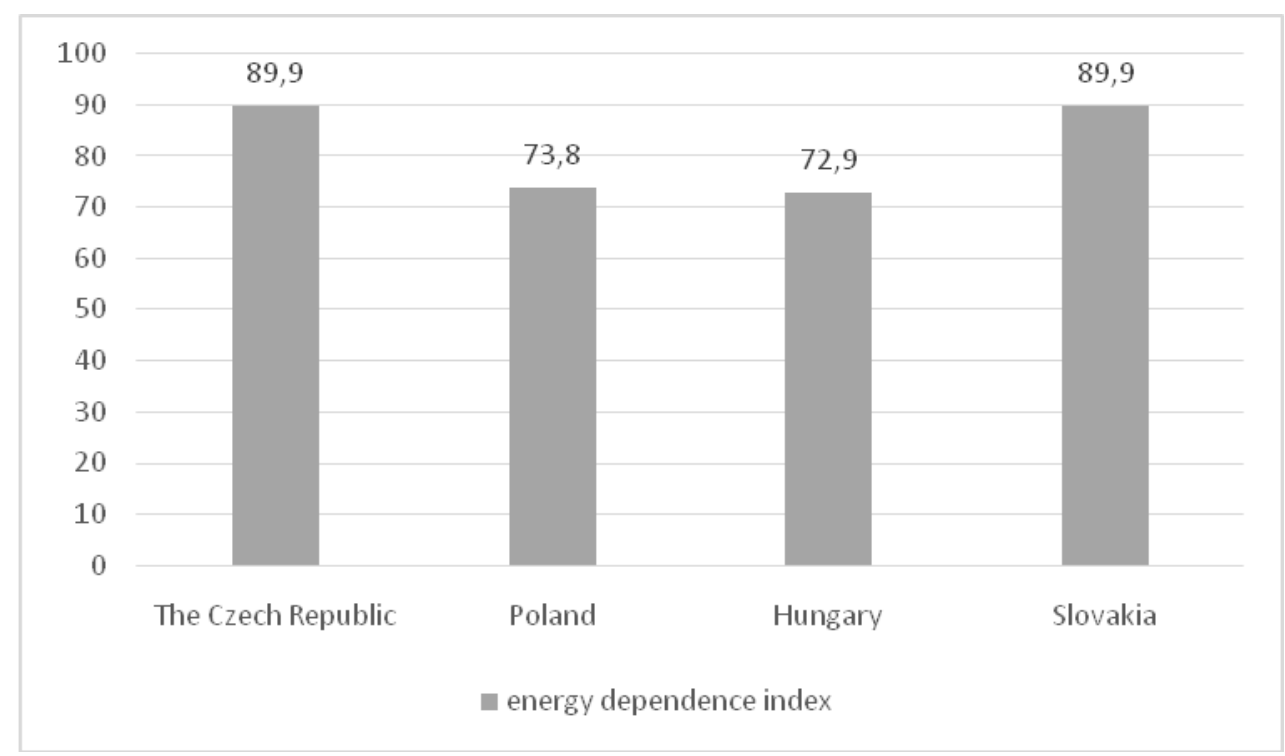

Sources: own elaboration based on: Energy, transport, and environment indicators 2014 edition, Eurostat, Luxemburg 2013,pp. 75.

The situation presented above show how many challenges for energy policy in the V4 countries are. This can become more visible by doing a SWOT analysis of energy security in the region (table 1). First of all, we should to notice that Central Europe has the key role in the EU. It is the link between Eastern and Western Europe. Although, the role was reduced by Nord Stream but the region has still opportunity to play important role to transit routes in the future. The first step which should be done is to change an approach to energy security in the V4 countries. The action should be focused on by a comprehensive and wide approach. The participation in some regional and subregional institutions is a positive change and belongs to instruments which build strong energy policy.

The goals determined by the V4 countries are coherent with goals determined by the EU. However, realisation of the goals (like diversification of suppliers or directions) is dependent on energy infrastructure which is existing. In addition without energy infrastructure there are no possibilities to implement regulations at EU level and to apply an effective EU solidarity mechanisms in the gas sector. This infrastructure enables to implement an effective EU solidarity mechanism in the gas sector and to ensure an appropriate response of the European Union relevant to the nature of the crisis situation ${ }^{9}$. In other words in the V4 countries we have not any alternatives if the energy crisis will. The shortage of common gas market in EU framework disqualifies the participation of states in the creation energy policy of the European Union. Also, there are existing routes

${ }^{9}$ J. Trubalska, Energy Union - a key concept in the EU energy policy, "Pulaski Policy Paper" 2015, No 1, pp.1-2 
of gas supply in this part of Europe, are not sufficient circumstance to take more favourable contracts of gas supply. Moreover, not every states had coherent policy energy. In this case the exceptions were Poland and the Czech Republic ${ }^{10}$. The situation has been changed slight after energy crisis in 2004. That time the EU defined the main actions towards the common energy policy. Also, the EU's countries were forced to redefinition of energy policy and energy security. Building energy infrastructure in the V4 countries can be a chance for the strengthen geopolitical position in the region by gas connection between the Baltic states and the rest of Europe. It seems that one of the important challenge is to complete European integration by the development of energy infrastructure networks that will connect Central Europe with the rest of the EU.

Table 1. SWOT analysis of energy policy in the V4 states

\begin{tabular}{|l|l|}
\hline Strengths & Weaknesses \\
\hline $\begin{array}{l}\text { Geopolitical situation } \\
\text { V4 participation } \\
\text { Well-developed bilateral relationship }\end{array}$ & $\begin{array}{l}\text { Lack of energy infrastructures } \\
\text { Lack of common solution of energy } \\
\text { security problem } \\
\text { Strong dependence by one supplier } \\
\text { Small gas resources } \\
\text { Regasification capability in the transit } \\
\text { routs }\end{array}$ \\
\hline $\begin{array}{l}\text { Opportunities } \\
\text { European Internal Energy Market } \\
\text { Common energy policy in the EU }\end{array}$ & Threats \\
\hline
\end{tabular}

Sources: own elaboration

The legal basis of energy infrastructure are regulated by many regulation in the EU ${ }^{11}$. It would seems that The Treaty on the Functioning of the European Union (TFEU) is a key document, so far. The XXI title of TFEU defines a goals of the EU, among the energy shall aim to: ensure the functioning of the energy market, ensure security of energy supply in the Union, promote energy efficiency and energy saving and the development of new and renewable forms of energy; promote the interconnection of energy networks ${ }^{12}$. The title XVI of the TFEU - Trans-European networks describe these matter, in particular. According to this articles the "Union shall contribute to the establishment and development of trans-European networks in the areas of transport, telecommunications and energy infrastructures" "13. In additional the EU shall aim at promoting the

\footnotetext{
${ }^{10}$ K. Pronińska, The Impact of Energy Cooperation of ..., pp. 119-123.

${ }^{11}$ e.g. Decision No 1229/2003/EC of the European Parliament and of the Council of 26 June 2003 laying down a series of guidelines for trans-European energy networks and repealing Decision No 1254/96/EC, OJ L176, 15/06/2003;Directive 2009/73/EC of the European Parliament and of the Council of 13 July 2009 concerning common rules for the internal market in natural gas and repealing Directive 2003/55/EC, OJ L 212, 14/08/2009.

${ }^{12}$ TheTreaty on the Functioning of the European Union OJ C 326, 26/10/2010, pp. 134.

${ }^{13}$ Ibid., pp. 124
} 
interconnection and interoperability of national networks as well as access to such networks. These action should create to link "energy island" between EU's countries. It is against this background, therefore, that we should consider the North-South Gas Corridor. Next steps towards a common regulation for energy infrastructure is Regulation (EU) No 347/2013 of the European Parliament and of the Council of 17 April 2013 on guidelines for trans-European energy infrastructure and repealing Decision No 1364/2006/EC and amending Regulations (EC) No 713/2009, (EC) No 714/2009 and (EC) No 715/2009 ${ }^{14}$. This Regulation lays down guidelines for the list of projects of common interest. Those kind of projects should be met the three general criteria, described below. First, the project is necessary for at least one the energy infrastructure priority corridors. Second, the potential overall benefits of the project, outweigh its costs, including in the longer term. In additional, the project is to contribute significantly both to market integration through eliminating the isolation of at least one Member State and reducing energy infrastructure bottlenecks. So, the projects should ensure security of supply i.e. through diversification of supply sources or supplying counterparts and routs ${ }^{15}$.

Also, the V4 countries has been pursuing to reinforce their energy security, in particular from 2010, when the first energy summit was held. During, the summit, the participants granted the indispensability of speak one voice about energy security in the region. Consequently, the Trans-European corridors are the main goal of energy security in the EU.

\section{THE NORTH-SOUTH GAS CORRIDOR}

The energy security or energy policy had not been the main issues to cooperation in the V4 framework until 2010. It was a consequence, how mentioned above, the different approaches in the states of this institution. The situation was changed after last gas crisis in 2009. The negative consequences were the milestone towards to build the energy security concepts in the V4. The first meeting washeld in $24^{\text {th }}$ of February in 2010 in Budapest. During the meeting Declaration of the Budapest V4+ Energy Security Summitwas received. The countries expressed due to support to strengthen cooperation in further integrating gas networks and diversifying routes and sources supplies. The goal will achieve by promoting and realisation the North-South Gas Corridor through all the V4 states between Polish and Croatian Liquefield Natural Gas terminals. It is the main goal the V4 at the moment. It has been first step to build the gas connections. The meaningful achievement of Energy Security Summit was accepted by countries the common direction of energy policy, like guaranteeing the EU security of energy supply, through infrastructure projects within and outside the EU. Also, in this year the Commission Communication "Energy infrastructure priorities for 2020 and beyond" 16 determined the main priorities of the EU in terms of energy infrastructure, among the project the NSGS was in the list.

In 2011, during the meeting of Energy Ministers was confirmed the need to support further development of cooperation in the energy sector. Indeed, the cooperation is important for the process of creating the European Internal Energy Market. In particularly, the ministers of energy were highlighted that energy cooperation in the V4 is an

\footnotetext{
${ }^{14}$ OJ L $115,25 / 04 / 2013$

${ }^{15}$ Ibid., p.47.

${ }^{16} \mathrm{COM}(2010) 677$ final.
} 
importantpart of the EU energy market. Participants of meeting accepted a proposal to development of mutual cooperation in all areas if energy and energy security by developing rules of cooperation in elaborating common the V4 opinions in the context of the EU institution and initiatives ${ }^{17}$. However, one of the main topic was energy infrastructure projects, which would allow physical access to at least two different gas sources from outside of the EU. It is agreed in the EU policy, that any countries can be depend on one supplier. According to the EU states should achievement a high index of diversification and should not be more than 30 per cent in one source.

At the same time, José Manuel DurãoBarroso declared that "new policy has to ensure that no Member State is isolated form the rest of Europe" and added that "key element needed for the market to succeed - the creation of a North-South energy corridor"18. At that time Donald Tusk, then prime minister of Poland promoted the European energy union, which achievement will not possible without energy infrastructure in this part of $\mathrm{EU}^{19}$.

The NSGC is founded both to exist many gas interconnections between countries and the extension to the energy infrastructure within countries, as well. That means the NSGC will consist by many gas connections, which have already existed and an additional energy infrastructure, like the underground gas storages. Thus, the NSGC will be consist of many parts and it requires the only to fill of interconnection. In practice, a cost of the project is divided by each country participates in the investment and it is an opportunity to supported by the EU financial instrument in 2014-2020 perspective, like Connecting Europe Facility. It should be consider that the Commission granted the NSGC on the list of Project of Common Interest (PCIs) in 2013. It should be noticed that until 2013 the individual parts of the NSGC were supported by few financial instruments ${ }^{20}$.

Nowadays, the NSGC is gradually implemented, but many parts of the projects have been underdeveloped, yet. Nevertheless, the goal of the NSGC is linking the LNG terminal at Swinoujscie Poland, and the LNG Adria, Croatian LNG terminals by to create many bilateral interconnection by Poland, the Czech Republic, Slovakia and Hungary ${ }^{21}$. The each parts of project are different level of advanced. Beside, how mentioned above the essence of the NSGC is fact that is building based on energy infrastructures have already existed. It means that each action concerns the gaps. These projects have already been completed. There are interconnectors between Bulgaria and Romania, Romania and Hungary, Hungary and Slovakia.The last interconnection ensured that Hungary's gas system was connected to almost all its neighbouring countries (beside Slovenia) ${ }^{22}$.

17 Declaration of V4 Energy Ministers, http://www.visegradgroup.eu/2011/declaration-of-v4energy, access on: 12/12/2011.

18 José Manuel DurãoBarroso, „Statement by President Barroso following his Following His Meeting with Donald Tusk, Prime Minister of Poland", speech delivered at the European Commission, January 31, 2011, http://europa.eu/rapid/press-release_SPEECH-11-55_en.htm ${ }^{19}$ J.Trubalska, Energy Union..., pp. 1-2.

${ }^{20}$ More: J. Trubalska, Bezpieczeństwo energetyczne..., vide.

${ }^{21}$ F. Ėernoch, J. Osièka, The Czech Republic: Bringing the Rest Closer to the West? [in:] NorthSouth Gas Corridor. Geopolitical Breakthrough in Central Europe, Ćwiek-Karłowicz J., Kałan D. (eds.),The Polish Institute of International Affairs, Warsaw 2013, pp. 15-18.

${ }^{22}$ A. Deák, Hungary: Collecting the First Dividends of Interconnectivity?, [in:] North-South..., pp. 21-22. 
LNG terminal in Swinoujscie should be initially in 2015, but at the moment Poland has some kind limit to send gas in the V4 countries even in the crisis situation. Indeed, there is existed the Czech Republic-Poland connection but it can supply only $0,5 \mathrm{bcm} / \mathrm{y}$. That is so important to coordinate all parts of project. The next gas connection, is the Czech Republic and Hungary. Also, Slovakia would connect with Poland by interconnector. However, the NSGC is a complicated project, which a lot of work and an effective management needs.

\section{SUMMARY}

The NSGC is the flag investment in the EU dedicates in Central Europe region, at the moment. If it activates, the geopolitical role of the region will be change. Taking into consideration the goals of the EU, it seems that the NSGC is essential for building the single energy market. Developing a North-South Gas Corridor enhancing energy security in the EU. The consequences of theNSGS are two dimension. Firstly, the elements of the project eliminating "energy islands" in the V4 countries. Secondly, the interconnections between countries connect to mainstream pipelines in the EU. In the future it will create an effective, single market in the EU. According the European Council the single energy market should be achievement by 2015 . However, these goals have not been fulfilled, yet.

The answer the first question about challenging and threats occur the region are focused on the capacity to regasification and the energy infrastructure solutions. The LNG terminal inŚwinoujscieseems that $5 \mathrm{bmc} / \mathrm{y}$ of gas imports is too little for ensure the energy security in the region, at all. Secondly,there is challenging which belongs to countries which can be supplier like United States or the Latin America countries, as well. Those directions allow the practical diversification of the direction to the EU. In addition, the US can lend support to pushing for the realization of the NSGC. The V4 countries is challenging to coordinate their energy policy, and the future say one voice in EU framework. The similarity conditions of energy policy in the V4 determinants the need to common ground. Indeed, it is necessity in the context to build the common energy policy in the EU. At now, the energy policy is based on the bilateral solutions, which weakens all the EU on this field. Moreover,each actionswhich have possibility ensure diversification influences on Europe's energy security and countries, as well. An analysis the main determinant of energy policy in the V4 and the EU countries shows that the week point for the further energy cooperation is lack of energy infrastructure. Without effective solutions there will not a chance to realization both common energy market and European energy union will stay the only idea. The proposal of energy security mechanisms are declaration for the V4 countries, which is an effect lack infrastructure solution. Also, the NSGC is challenging for Russia, which is still the dominant supplier in the V4 countries. The build the project can improve the energy dependent on the V4 countries. In consequences, their sensitivities and vulnerabilities of the states is improving. The countries will not so weak if the throughput balances between supply and demand. The geopolitical role of Central Europe should be more distinct than before in the EU framework. After realization the voice of the countries the analysis region will be more clearly and towards common direction more visible. It is important in the context to build common energy policy, which it seems countries should to build the coalition to ensure realization their goals. Moreover, the Czech Republic, Poland, Hungary and Slovakia have to access to alternative supplies, and it is the add value in this investment. 
The NSGC is meaningful both countries and the EU. The condition of energy policy in the EU is described by the weakness part. In this case the weak part is the Central Europe's countries. Improving their condition in the individual countries influences for circumstance of energy policy and energy security the whole EU. Right now, the V4 countries should to define common goals and implemented theirs in the EU. The Commission promotes new connections between countries, because the only action ensures energy security in the EU now and the future.Due to complete the European energy market and to ensure regional energy security need for a regional approach. In view of the different interests the old EU states than the V4 countries should to cooperation in this sector, constantly.

\section{REFERENCES}

[1] Communication from The Commission Europe 2020. A strategy for smart, sustainable and inclusive growth, $\operatorname{COM(2010)} 2020$ final, Brussels, 03.03.2010.

[2] Communication from The Commission to the European Parliament and the Council - European Energy Security Strategy, COM(2014) 330 final.

[3] Communication from The Commission to the European Parliament and the Council - An Energy Policy for Europe, COM(2007) 1 final, Brussels, 10.01.2007.

[4] Communication From the Commission to the European Parliament, the Council, the European Economic and Social Committee and the Committee of the Region. Energy infrastructure priorities for 2020 and beyond - A Blueprint for an integrated European energy network, COM (2010) 677 final, Brussels, 17.11.2010

[5] Consolidated versions of the Treaty on European Union and the Treaty on the Functioning of the European Union, OJ C 83, 30.03.2010.

[6] Decision No 1229/2003/EC of the European Parliament and of the Council of 26 June 2003 laying down a series of guidelines for trans-European energy networks and repealing Decision No 1254/96/EC, OJ L176, 15/06/2003.

[7] Directive 2009/73/EC of the European Parliament and of the Council of 13 July 2009 concerning common rules for the internal market in natural gas and repealing Directive 2003/55/EC, OJ L 212, 14/08/2009.

[8] Regulation (EU) No 347/2013 of the European Parliament and of the Council of 17 April 2013 on guidelines for trans-European energy infrastructure and repealing Decision No 1364/2006/EC and amending Regulations (EC) No 713/2009, (EC) No 714/2009 and (EC) No 715/2009, OJ L 115.

[9] Report From the Commission to the European Parliament and the Council - On the Complementation of the European Energy Programme for Recovery, COM (2014) 669 final, Brussels, 28.10.2014.

[10]The Treaty on the Functioning of the European Union OJ C 326, 26/10/2010.

[11]Declaration of V4 Energy Ministers, http://www.visegradgroup.eu/2011/declaration-of-v4-energy, access on: $12 / 12 / 2011$.

[12]José Manuel DurãoBarroso, „Statement by President Barroso following his Following His Meeting with Donald Tusk, Prime Minister of Poland", speech delivered at the European Commission, January 31, 2011, 

02/02/2011

[13]BP Statistical Review of World Energy June 2014, access on: bp.com/statisticalreview

[14]Energy, transport, and environment indicators 2014 edition, Eurostat, Luxemburg 2013.

[15]Bauman F., Energy Security as multidimensional concept, "CAP Policy Analysis" 2008, No 1.

[16]Ćwiek-Karłowicz J., Kałan D. (eds.), North-South Gas Corridor. Geopolitical Breakthrough in Central Europe, The Polish Institute of International Affairs, Warsaw 2013.

[17]Deák A., Hungary: Collecting the First Dividends of Interconnectivity?, [in:] North -South Gas Corridor. Geopolitical Breakthrough in Central Europe, Ćwiek-Karłowicz J., Kałan D. (eds.), The Polish Institute of International Affairs, Warsaw 2013.

[18] Ėernoch F., Osièka J., The Czech Republic: Bringing the Rest Closer to the West? [in:] North -South Gas Corridor. Geopolitical Breakthrough in Central Europe, Ćwiek-Karłowicz J., Kałan D. (eds.), The Polish Institute of International Affairs, Warsaw 2013.

[19]Pronińska K., The Impact of Energy Cooperation of Central Europa Countries on the Regional Energy Policy of the EU, The Natolin European Central, Warsaw 2013.

[20]Ruszel M., Security in the natural gas supplies to the countries of the Visegrad Group, International Multidisciplinary Scientific Conferences on Social Sciences \& Arts, SGEM Conference on Political Sciences, Law, Finance, Economics \& Tourism, 3-9 September 2014, Bulgaria (ISSN: 2367-5659), Conference Proceedings, Volume 1, Albena 2014.

[21]Trubalska J., Bezpieczeństwo energetyczne Rzeczypospolitej Polskiej, Polskie Towarzystwo Geopolityczne, Kraków 2015.

[22] Trubalska J., Energy Union - a key concept in the EU energy policy, "Pulaski Policy Paper" 2015, No 1.

[23]Turowski P., Bezpieczeństwo dostaw gazu dla Grupy Wyszehradzkiej i pozostałych państw Unii Europejskiej, „Bezpieczeństwo Narodowe” 2014, No 2, Biuro Bezpieczeństwa Narodowego, Warszawa 2014.

\section{TRANSEUROPEJSKIE PROJEKTY ENERGETYCZNE NA PRZYKLADZIE} KORYTARZA GAZOWEGO PÓŁNOC-POLUDNIE

Bezpieczeństwo energetyczne stanowi istotny składnik bezpieczeństwa państw. Wśród wielu elementów mających wpływ na bezpieczeństwo energetyczne państwa wydaje się, że kluczowe znaczenie dla jego realizacji ma wymiar infrastrukturalny, który odnosi się zarówno do infrastruktury przesyłowej, odbiorczej oraz magazynowej. Znaczenie wymiaru infrastrukturalnego bezpieczeństwa energetycznego jest warunkowane, co najmniej dwoma czynnikami. Po pierwsze, wynika z samego faktu konieczności zapewnienia stałych i ciągłych dostaw gazu ziemnego. Po drugie, warunkuje pozycję państwa w regionie. Zatem posiadanie infrastruktury energetycznej stanowi sine qua non bezpieczeństwa energetycznego. Biorąc po uwagę zmieniającą się sytuację międzynarodową, rosnące zapotrzebowanie na gaz ziemny w państwach Grupy Wyszehradzkiej, istnieje potrzeba 
rozbudowy połączeń infrastrukturalnych. Do tego typu projektów należy korytarz gazowy północ - południe, który obejmuje Polskę, Czechy, Węgry, Słowenia, Chorwację oraz Rumunia. Inwestycja ta stwarza szanse na zwiększenie bezpieczeństwa energetycznego w regionie, poprzez zapewnienie dywersyfikacji kierunków i źródeł dostaw gazu ziemnego. Niemniej jednak w kontekście zmieniających się uwarunkowań należy odpowiedzieć na kilka pytań. Po pierwsze, jakie znaczenie dla UE i państw realizujących inwestycje ma budowany korytarz północ - południe. Po drugie, jakie szanse niesie za sobą realizacja projektu. I w końcu czy budowa korytarza wpłynie na rolę geopolityczną regionu Europy Środkowej?

Celem niniejszego artykułu jest próba odpowiedzi na główne pytanie, jaka jest rola korytarza gazowego do Unii Europejskiej. Artykuł został podzielony na trzy części. W pierwszej części przedstawiono wspólne cechy państw uczestniczących w realizacji inwestycji. W drugiej część poddano analizie aktualny stan prac. W trzeciej część podjęto próbę podsumowania i odpowiedzi na pytanie o rolę korytarza dla UE i państw Grupy Wyszehradzkiej.

Slowa kluczowe: bezpieczeństwo energetyczne, infrastruktura energetyczna, Grupa Wyszehradzka, polityka energetyczna.

DOI:10.7862/rz.2016.hss.13

Przesłano do redakcji: wrzesień 2015

Przyjęto do druku: styczeń 2016 